\title{
Dimension of Migration - Challenge or Concern for European Future?
}

Monika Nová

Hussite Theological Faculty, Institute of Legal History, Prague, Czech Republic

\begin{abstract}
Migration is a significant process through which the dynamics of population on the move substantially affect the long-term development of mankind. During the recent sixty years, a host of citizens of the world have enjoyed improvements in the key indicators of development, such as the life expectancy and access to education and/or medical services, though, admittedly, this rule does not apply to all countries and all regions. Relying on her argument on historical facts complemented by current events, the author of the paper presents the chosen subject of migration as it relates to the European future and to the demographic patterns of migration. The article deals with the current wave of migration - it is about integration and people on the road. The arguments that the author puts forward rely, inter alia, on her personal experience gathered in a refugee camp a.k.a. the hotspot.
\end{abstract}

Keywords: European future, Demographic development, Migration

\section{Introduction}

Relying on her own practice and personal experience, the author builds her argument on historical facts and supports her reasoning by what has already been published in books written by sociologists and Arabists. The paper presents some selected results of research performed among African Muslims in Uganda and other subjects.

As experienced today, the migration from Near East to Europe seems to be logical. Half of the migrants do not leave for Europe but they move to richer Arabian countries in the Persian Gulf, Libya and Asia (Černý, 2016). The Arab world is passing through development observed in Europe between the end of the 18th century and the beginning of the 20th century when Europe witnessed a population explosion followed by mass migration to other continents. At the early stage of such process, the mortality figures typically go down while natality remains relatively high, at least for some time, and population grows. This is what is called the period of demographic transition. The concept of demographic transition may help us understand what happens in the Arab world - the explosively increasing number of people, particularly young people, brings in political instability. Inspired by the historical development in Europe, the model of demographic transition is instrumental in comprehending the causes of the instability. A publication by Černý, a sociologist, ascribes a great importance in the process of destabilization to the growing population than to any religious discussions and speculations. Arab countries are obviously going through the same tempestuous changes as those triggered previously by population explosion in Europe. The number of inhabitants (especially the young ones) rises, and the fact translates itself into political instability. Černý believes that the Near East instability can be attributed rather to the growth of population than to the extensively discussed topic of political Islam. The young generation of the Arab countries has reached the phase known as the "political storming".

Having examined the historical record of the European continent, we can see that Europe tackled the population explosion and the destabilization it entailed by simply "packing the 


\section{Monika Nová \\ Dimension of migration - Challenge or concern for European future?}

young people off" the continent. In this way (as sociologists and historians remind us) the "pressurized" space of Europe was in the 19th century gradually relieved by large-scale migration of Europeans, primarily to North America and later on to also Australia and New Zealand. The demographic surge per se would not have to exacerbate the migration problem so much. The situation, however, is aggravated by the economic development lacking behind the population growth as regards first and foremost new job opportunities. Another stumbling block rests in the rigidity of political systems - the Near Eastern countries are increasingly unable to govern their own territories, as apparent, for instance, from the inability of centralized Arab states to keep in check the rising number of weapons distributed among their citizenry. In Egypt even the middle classes try to acquire weapons to protect their families (Černý, 2017). Though highly authoritarian and claiming exclusive control over using force, these countries cannot guarantee their citizens adequate level of safety, summarizes Černý. Moreover, they are incapable of routinely providing social services and other essentials, a fact making the life sort of difficult. In effect, despite their authoritarian nature, the countries protect neither individuals nor families (Černý, 2016).

Islam is a factor capable of cutting both ways. Western Europe, on the one hand, tends to accentuate the destabilizing potential of the religion, mentioning specifically the radical political Islam as manifested in the Islam state, the Al Qaeda organization and various terrorist groups present more or less in all Arab countries since the 1970s.

On the other hand, Islam may do the duty of a stabilizing element in social solidarity and justice. In the Near East region the Islamic society can play a prominent role in substituting for the collapsing and increasingly dysfunctional governments. Organizations associated with mosques and/or other places of worship take on charitable work, run hospitals, provide healthcare, distribute clothes, offer courses to adults, arrange special-interest groups for kids, organize leisure-time activities for teenagers, etc. Acting in the place of government, the Islamic movement and Islamic charity often deliver social care and undertake tasks already abandoned by the state, thus long-term contributing to the stability of the relevant regions. Both literature, professional articles (Crawley 2017, Bartram 2012) and the author's handson experience lead us to believe that in Islam the belief in God is immediately followed by the belief in family, namely a multigenerational family, wherein the generations mutually support and help each other. These supportive family ties are deeply embedded in religion and, in a way, their nature is a matter of culture. Close-knit families are stable families, and this fact is pivotal in stabilizing the entire region. Whenever a person or a nuclear family cannot rely on the state, they turn to their extended family or to the Islamic society.

\section{Method}

The paper presents a selection of results yielded by the author's own research and employed to provide arguments valid for the chosen subject. The research applied the technique of inperson individually conducted semi-structured interviews (the face-to-face method) broken into partial research questions whose sequence led the respondents to think about their demands. The data thus obtained were analyzed and interpreted by the open-coding method. To make the sample sufficiently heterogeneous, the participants were selected purposefully, the sole conditions being their Muslim faith and their long-term residency in a Muslim region. The effort resulted in fourteen interviews carried out between November 2017 and January 2018 in five Ugandan villages (district Ntumgamo) with Muslim population. Each interview lasted 60 minutes on average. To operationalize the research and to facilitate the analysis of collected data, the partial research questions had assigned to them the easily recognizable indicators or markers specified below (Disman, 2000). 


\section{Monika Nová \\ Dimension of migration - Challenge or concern for European future?}

\subsection{Partial Research Questions and Indicators}

Partial research question 1: Do you wish to move to Europe?

Indicators: distinctive features of environment; knowledgeability and skills of inhabitants; financial situation; job opportunities.

Partial research question 2: What are your educational, healthcare and social care needs?

Indicators: quality elementary schools; availability of healthcare; maternity clinics and pregnancy assistance; leisure-time facilities for kids; care for the dying.

When theoretically understood and properly conceptualized, the key terms allowed us to choose a sufficiently heterogeneous sample adequately representative of the entire spectrum. Before conducting the interviews, we sought to become thoroughly familiarized with the environment so that we could find our way in a surfeit of information, avoid preconceptions based on our previous experience of developmental aid and thus were able to interpret the respondents' replies undistorted by our professional expectations. The participants were told the purpose of the research beforehand.

\section{Results}

Below you will find a partial summary capable of fully responding to the main research question and followed also by a space wherein the analyzed topic can be discussed. The analysis was accompanied by direct quotations of participants' answers, but to keep the scope of this paper manageable, we have chosen not to include them.

\section{Summary of Partial research question 1: Do you wish to move to Europe?}

This information is absolutely essential to find out whether the participants plan to leave their country or not. The participants do not wish to move to Europe or to any other foreign country. Despite having to cope with all sorts of adverse social occurrences, their families feel closely tied to the region and their internal solidarity allows them to live even in dire circumstances. The participants are well aware that the cost of the journey is beyond their means. Moreover, they appreciate their own educational insufficiency. In spite of their limited knowledge of geography, they perceive Europe as a country too remote to reach. They expect harmful consequences, primarily the disruption of the family, even if just a single member should leave to live outside the family. This negative expectation is exacerbated by the fact that the leaving persons are typically males, husbands or elder sons, and the task of providing for the family thus passes onto females.

Our research and years of relevant practice in Africa show that another crucial issue (the same as encountered in the Near East) lies in the growth of younger generations wishing to graduate and get jobs. Scarcity of vacancies, however, may then allow the young people a scope for indulging in socially pathological behavior. In our practice we have witnessed an increased number of girls and young women involved in the sex business, petty theft, car holdup and criminal assaults against people (without killing anyone).

\section{Summary of Partial research question 2: What are your educational, healthcare and social care needs?}

Following from the first research question, the second one inquired into the specific requirements for education, healthcare and social care that were specified by persons living in the given region. The feedback thus obtained revealed also opportunities for implementing projects organized from abroad and/or for encouraging private donors who might consider funding centers for relevant activities. Acquiring this information was necessary for disclosing the needs that the locals may have. The research results thus unveiled gaps in the social and 
health sectors. Asked to specify the target groups, the participants mentioned children, women and the dying. As regards education, the local teachers should be better educated or successful graduates of local universities should be recruited. Missing educators can be replaced by volunteers from Europe or other countries of the world. A greater number of properly trained midwives are needed. The results also indicate an increasing demand for palliative care and a total absence of palliative care provided in the field.

All the mosques that we visited during our research were very effective in offering public courses to children and adults (focused on using computers; making clothes; working with wood, etc.) as well as in organizing remedial and special-interest courses for small children. The needs identified by the participants as still unsatisfied were the same as those mentioned above - they can inspire new projects and be of interest for foreign sponsors, grant agencies and foreign embassies.

\section{Results and Discussions}

The paper is a qualitative study aimed to treat the subject of Muslim community and their plans to move abroad. The methods chosen for the study were (1) qualitative research and (2) interview.

The research results can be of interest to non-profit organizations in Europe and other countries of the world; to sponsors, foreign investors, philanthropists and others. They could help to bring into existence the facilities still missing, whose absence might further deteriorate living conditions, and tell the potential supporters what needs to be built for the region's inhabitants. Even though the participants covered in our research do not consider leaving their region or home country, their worsening quality of life could force them to change their mind - that is why their well-being in a matter of consequence.

Speaking about the African state of Uganda and judging by our own practical experience from Malawi and Rwanda, also countries with numerous Muslim regions, our research leads us to believe that the local Muslims, though poor, do not want to leave their familiar environment and would prefer to have their quality of life improved particularly by better healthcare, social care and new job opportunities for the young generation coming of age and wishing to begin a gainful occupation.

Concerning the Near Eastern regions, the situation is characteristic of lax security that the local government is capable of providing to the inhabitants. What is more, the circumstances are aggravated by the large arsenal of weapons possessed by citizens. In consequence, the government loses its exclusive control over using force and the regions grow lawless. In contrast to the Near East, the army and police of the above-mentioned African countries do a relatively good job protecting the local civil population, and the people are not prone to carry weapons. We have found that the Near East inhabitants are often better positioned to leave for Europe because their financial situation is not as stressful as that of the African Muslims.

Regarding the relevant sociological indicators, we have treated below also problems possibly entailed by the transfer to Europe:

On the one hand the Near East and African countries of our interest are typically abandoned by qualified workforce (brain drain) and the situation gradually develops into a shortage of labor. On the other hand migration has also positive consequences. The migrants remit back home billions of dollars and thus provide a sort of social support to their families. Author Ackers (2005) later author Bal, Willems (2014) have noted, our practical experience tells us that after some time the strong family ties lead to the rest of the family joining their relatives in Europe or any other country of the world. This frequently happens even if the newcomers have no 


\section{Monika Nová \\ Dimension of migration - Challenge or concern for European future?}

jobs pre-negotiated. They simply rely on landing a job, but their chances of success (e.g. in Germany and despite developing digitization) are still slim even in services and blue-collar occupations (Nová, 2016). This process generates groups of unemployable people who were better off in their home countries receiving money sent by a single member of the family.

Our lessons learned in the Near East should serve as a blueprint for providing remote village regions of Africa with social, healthcare and educational services, and particularly with new job opportunities. The recent fourty years have witnessed an exodus of village people to big cities. The exodus and the ensuing urbanization altered the character of society and resulted in political instability. A large number of people crowded within a limited living space are easily disgruntled. Sociologist Černý believes that such people are susceptible to ideology and readily involved in collective actions. Young migrants can also be greatly influenced by media and easy access to social networks where the life in Europe is depicted as the life in affluence. The Near East regions are densely populated with young persons, but they are very modern. By comparison, the Muslim regions in Africa are also densely populated with young persons, but they stick to the tradional culture. Examining sociological indicators, we can see that the numbers of people moving out of the Near East tend to drop when the population explosion is substantially over. This situation has already been witnessed in some countries - for example Tunis has undergone this process.

Another reason why people leave their home countries lies in their poor identification with the nation, the nation's representatives and its politics. The Near East states came into existence after the dissolution of the Ottoman Empire in the aftermath of WWI. Their borders were drawn up artificially, a fact to which the current instability can be partially attributed. Research performed by Černý (Černý 2016) suggests that about one third to one half of people living in Arab countries identify with their states. Approximately one third of them identifies with the entire Pan-Arabic space split into more than 20 states. The remainder identifies with the PanIslamic Ummah, i.e. with all Muslims. In other words, they perceive themselves primarily as Muslims. Besides, Muslims in regions identify themselves with their extended families. These observations contrast with what can be seen in Europe. Europeans identify themselves first and foremost with their nation. That is why the decision of leaving the home country and moving with the whole family to a different environment is easier for the people from the Near East. The opinion that the current migrants may fill in job vacancies and will thus be ultimately beneficial for the European economy contrasts with concerns expressed by the World Economic Forum (Fransen, Riuz, Vargas-Silva, 2017). Debating the subject of automatization in relation to the anticipated implementation of sophisticated technologies in Europe, the Forum developed these expectations: unemployment will grow even in developed European countries; the phenomenon will be strongest in Germany, where the number of vacancies will be reduced by automatization; therefore, the migrants can hardly be perceived as needed workforce. In addition, the Oxford analyses indicate that the situation is grave - too few job opportunities for too many job seekers. Germany, for instance, will face the consequences of automation already implemented within 5 years. Redundancy threatens especially the blue-collar positions occupied by migrants who can hardly be requalified to become IT specialists overnight. Taken into account must also be the language barrier; the level of education; and the work habits and competencies. Europe can learn a useful lesson from the situation in the United States: the influx of unskilled labor unable to speak English put USA at the cutting edge of automated industry. It resulted in the emergence of working poor; the distribution of food aid; and the rise in crime figures attributable to unemployment. Different forms of social exclusion can be encountered perhaps in all traditional societies and the same can be said of socially excluded individuals, groups and categories of people (Cummins, 2018). The socially excluded people are cut off institutions and services, social networks and educational opportunities. Counted among factors typical of social exclusion can thus be long-time unemployment, dependence on social benefits, living in spatially separated parts of communities (ghettoes), low qualification, poor health, disintegration of families and the loss of self-esteem (Nová, 2016). 


\author{
Monika Nová \\ Dimension of migration - Challenge or concern for European future?
}

\title{
5. Conclusions
}

Every year millions of people leave their homes. Proper investigating, mapping and understanding the problem of migration is a matter of consequence not only for the first transit countries but for all who are affected by the phenomenon. We should perceive each migrant as a human being with a story to tell. Before everything, he or she had to muster the courage to set out on the journey. Related to the population of Europe, the percentage of newcomers is too small to be dangerous. Should the risk be greater than neglibible, their numbers would have to be higher and the process longer. Relying on what she experienced on the Balkan route of migration, the author believes that, even when making the decision, a good deal of the migrants do not expect a better life in Europe. Many are convinced that all they need to improve their life is greater security, better education, better healthcare and social care, and above all new job opportunities. With these facts of life available, a host of the people would not be led to consider leaving their homes. The future, however, has in store some environmental themes that will burden the Arab countries and the North of Africa in the years to come. Climate changes in the region and the exodus they could trigger will become, or have already become, a topic of political debate.

\section{Acknowledgments}

The theme and research of this paper Dimension of migration - Challenge for European future or concern? was realized from the project: NAKI II Právní, historické a společenskovědní aspekty nových a tradičních menšin v České republice.

\section{References}

- ACKERS, L. 2005. Moving People and Knowledge: Scientific Mobility in the European Union. In International Migration. Vol 43 (5): 99-131. Geneva: INT Organization Migration. ISSN: 0020-7985

- BAL, E., WILLEMS, R. 2014. Aspiring Migrants, Local Crises and the Imagination of Futures "Away from Home". In Identities-Global studies in culture and power. Vol. 21 (3): 249-258. USA: Taylor \& Francis INC. ISSN 1070-289X. eISSN: 1547-3384

- BARTRAM, D. 2012. Migration, Methods and Innovation. In. Vargas-Silva, C. Handbook of Research Methods in Migration. UK: Centre on Migration, Policy and Society, University of Oxford. ISBN: 9781849803113

- Crawley, H. et al. 2017. Unravelling Europe's migration crisis. Bristol: Policy Press at the University of Bristol ISBN-10: 1447343212

- Cummins, I. 2018 Poverty, Inequality and Social Work. Bristol: Policy Press at the University of Bristol. ISBN: 9781447334828

- Černý, K. 2017. Velká blízkovýchodní nestabilita. Praha: Nakladatelství Lidové noviny. s.580. ISBN 978-80-7422-514-7.

- Černý, K. 2015. Nad Evropou půlměsíc. Praha: Karolinum. s.280. ISBN 9788024630663.

- Černý, K. 2012. Svět politického islámu. Praha: Karolinum. s.592. ISBN 978-80-7422-1668.

- Černý, K. 2016. Význam kmenové společnosti v 21. století. Praha: Nakladatelství Lidové noviny. s.160. ISBN 978-80-7422-426-3.

- Disman, M. 2000. Jak se vyrábí sociologická znalost. Praha: Karolinum. ISBN 80-246-01397

- Fransen, S., Riuz, I., Vargas-Silva, C. 2017. Return Migration and Economic Outcomes in the Conflict Context. Science Direct: World Development vol.95 (196-210). Oxford: University Oxford

- Nová, M. 2016. Migration - Models and Principles of Immigrant Integration. In Kovářová, E., Melecký, L., Staníčková, M. (eds.). Proceedings of the 3rd International Conference on European Integration. Ostrava: VŠB - Technical University of Ostrava, pp. 673-678.2016. ISBN 978-80248-3911-0. 